\title{
Strength Modeling of High Strength Concrete
}

\author{
Zealakshmi $\mathrm{D}^{1}$, Ravichandran $\mathrm{A}^{2}$,Kothandaraman $\mathrm{S} \mathrm{K}^{3}$ \\ (Civil Engineering, Christ College of Engineering \&Technology/ PondicherryUniversity, Pondicherry) \\ (Civil Engineering, Christ College of Engineering \&Technology/ PondicherryUniversity,Pondicherry) \\ (Civil Engineering, PondicherryEngineering College/ PondicherryUniversity,Pondicherry)
}

\begin{abstract}
Silica fume is being used all over the world for many years in the area where high strength and durable concrete were required, and it also improves the characteristicsof both fresh and hard concrete. Incorporation of the silica fume increases the mechanical properties of high strength concrete than the conventional concrete. Standard cylinders and standard prisms were considered in this study and the specimens were cast with and without silica fume. Mechanical properties such as compressive strength, split tensile \& flexural strengths of high strength concrete of grade M60 were determined with various replacement of silica fume ranges from $0 \%$ to $15 \%$. The experimental results of this research indicate that the optimum percentage of silica fume in concrete is $12 \%$.

This paper presents the mathematical model for predicting the strength of the silica fume high strength concrete. The result from this studyrecommends that the model hasachieved remarkably well in predicting the strength of concrete mix.
\end{abstract}

Keywords: Silica fume, High strength concrete, Mineral admixtures, hyper plasticizer, mathematical model.

\section{Introduction}

High strength concrete enhanced with silica fume which provides architects and engineers with greater design flexibility and it is used for constructing high rise buildings for the benefit of smaller columns thereby increasing usable space.

Naturally, the mechanical properties of high strength concrete will be improved further by adding several mineral admixtures such as silica fume, Fly ash, Ground granulated blast-furnace slagect,.Among these silica fume has utilized in this research work.

Silica fume is very fine non crystalline powder produced in an electric arc furnacesand itis a by-product of the manufacture of silicon metal and ferro-silicon alloys. It was initially viewed as a cement replacement material in order to control air pollution, but currently the most important reasons for its use is the production of high strength concrete with enhanced compressive strength with very high levels of durability.

Silica fume produces concrete that is stronger and more durable than conventional concrete. Adding up to $5 \%$ of silica fumes by weight of cement makes a little difference whereas by adding higher amount of silica fume reduces bleeding and more susceptible than the conventional concrete.

To achieve a maximum improvement in strength and workability, high-range water-reducing admixture (HRWRA) has beenused.

Several techniques have been applied to civil engineering problems in general and structural engineering in particular and also a comparative study between the different techniques carried out in different aspects like strength of concrete mix. In this study the suggested model such as linear regression is very modest and easy compared to the other models for the prediction of the results.

\section{Few literatures are briefly explained in the following text:}

\section{Review Of Literature}

Umeshsharma et al .[1] highlighted physical and chemical properties of micro silica reported about the fineness of silica fume which decreases the voids and reduces capillarity,Absorption and porosity thereby silica fume improves the quality of concrete.Bhanja \&Sengupta [2] investigated the influence of silica fume on the tensile strength of high performance concrete in which he has concluded that the incorporation of silica fume in concrete shows significant improvement in the tensile, splitting tensile and compressive strength in the range of $5-10 \%$ replacement level of silica fume. Amudhavalli\& Jeena Mathew [3] investigated the combined effect strength and durability of normal concrete in different $\%$ of SF replacement with ordinary Portland cement, and he reported that silica fume seems to have more pronounced effect on the flexural strength than the split tensile strength. MuhannadIsmeik [4] investigated the effect of mineral admixtures on mechanical properties of high strength concrete with locally available materials and hence based on his findings compressive and flexural strength found higher the normal concrete and compared the values with prediction equation. Mohammad Panjehpour et al.[5] studied the characterization of silica fume and its effects on concrete properties and 
summarized the overall effects of silica fume in concrete such that it increases the strength and decreases the permeability ,workability and coefficient of thermal expansion and enhances the dispersion of micro fibers and bond strength with steel fibers. Swami et al. [20] investigated about the optimum percentage of silica fume as a replacement for cement in concrete and therefore he has concluded that $10 \%$ of silica fume gives better results with water cement ratio is 0.5 and he has also recommended that micro silica is an useful admixture to enhance the durability of even in an aggressive environment consisting of sulphates.

With the knowledge of several literatures, the main aim of the present study is to develop the low cost construction material by using supplementary cementitious composites as a partially or fully replacement of cement without affecting its quality ,strength and other characteristics.

\section{Aim And Objective Of The Present Study}

To investigate the mechanical properties i.e., Compressive strength, Tensile \&Splitting tensile strength,flexural strength of concrete at different replacement levels of cement by silica fume are selected as $0 \%, 3 \%, 6 \%, 9 \%, 12 \%$ and $15 \%$ for standard cylinders and prisms and to develop the mathematical model for strength prediction.

\subsection{Materials used 4.1.1 Cement}

The cement used in concrete was ordinary Portland cement 53 grade as per IS12269-1987. And its specific gravity is

\subsubsection{Aggregates}

The sand used was local river sand and the coarse aggregate whose maximum size is $12.5 \mathrm{~mm}$ their general properties are mentioned below in Table: 1

Table 1 Property of Aggregates

\begin{tabular}{|l|c|c|}
\hline \multicolumn{1}{|c|}{ Properties } & Fine Aggregate & Coarse Aggregate \\
\hline Specific Gravity & 2.4 & 2.74 \\
\hline Fineness Modulus & 3.12 & 8.67 \\
\hline $\begin{array}{l}\text { Bulk Density } \\
\left(\mathrm{kg} / \mathrm{m}^{3}\right)\end{array}$ & 1589 & 1643 \\
\hline
\end{tabular}

\subsubsection{Silica fume}

\section{Experimental Program}

Silica fume used was a commercially available micro silica grade 920 (Undensified 920 D) whose specific gravity and bulk density is 2.22 and $500-700 \mathrm{~kg} / \mathrm{m} 3$ which improves concrete properties in fresh and hardened states.

\subsubsection{Super plasticizer}

To improve theworkability of concrete, a high-range water-reducing admixture [hyper-plasticizer] by a trade name classic super flow SP (Naphthalene Sulphonate) was used during mixing operations. It is available in brown liquid instantly dispensable in water and its specific gravity is 1.2.

\subsection{Preparation of Test Specimen}

As per ACI 211.4R - 93 mix design has been calculated and mentioned below in Table: 2

Table 2: Concrete Mix proportion of high strength concrete

\begin{tabular}{|l|l|l|}
\hline Sl. No & Material & Quantity \\
\hline 1 & 53 Grade cement $\left(\mathrm{kg} / \mathrm{m}^{3}\right)$ & 467 \\
\hline 2 & Sand $\left(\mathrm{kg} / \mathrm{m}^{3}\right)$ & 600 \\
\hline 3 & $\begin{array}{l}\text { Coarse aggregate }\left(\mathrm{kg} / \mathrm{m}^{3}\right) \\
12.5 \mathrm{~mm} \text { size }\end{array}$ & 1035 \\
\hline 4 & Water $\left(\mathrm{kg} / \mathrm{m}^{3}\right)$ & 158 \\
\hline 5 & Silica fume $\left(\mathrm{kg} / \mathrm{m}^{3}\right)$ & 45 \\
\hline
\end{tabular}

\subsection{Casting and Curing}

The specimens were cast in batches, each batch consisting of three cylinders $(150 \mathrm{~mm}$ dia X $300 \mathrm{~mm}$ height) for compressive strength, three cylinders $(150 \mathrm{~mm}$ dia X $300 \mathrm{~mm}$ height) for splitting tensile strength and three prisms $(100 \mathrm{mmX} 100 \mathrm{mmX} 500 \mathrm{~mm})$ for modulus of rupture with different replacement levels of silica fume with cement.. The specimens were cast in steel moulds and consolidated using vibrating table. All specimens were demoulded after 24 hours of casting and they were cured under water for 28 days before being tested. 
As per mix design required quantity of silica fume and cement were spread out in an impervious floor and then followed by fine aggregate, coarse aggregate and mixed well (manual mixing) with water to attain consistent mixture of concrete .To ensure proper workability, the slump was maintained in the range of $25-50 \mathrm{~mm}$ by the addition of hyperplasticizer (classic super flow PC 8860). The time taken for mixing is 10-15 minutes.

\subsection{Discussion of Test Results}

The present investigation reports a part of a comprehensive study intended to determine thecontribution of silica fume on M60 concrete with a w/c ratio of 0.33 and cement replacement levels from 0 to $15 \%$.The optimum silica fume replacement level and strength improvement of high strengthconcrete have been determined. Compressive strength, Split tensile strength and Flexural strength at 28 days silica fume concrete continuously increased when compared to the normal concrete.

With reference to the experimental results, by applying Regression analysis an equation has been developed and predicted the compressive strength $\left(\mathrm{f}^{\prime}{ }_{\mathrm{CS}}\right)$ Split tensile strength $\left(\mathrm{f}_{\mathrm{SP}}\right)$ and Flexural strength $\left(\mathrm{f}_{\mathrm{R}}{ }_{\mathrm{R}}\right)$ of hybrid fiber high strength concrete with different percentage of silica fume.

\subsubsection{Compressive Strength}

To find the compressive strength of the silica fume high-strength concrete, the cylinders were loaded in the compression testing machine $(2000 \mathrm{kn})$ as per ASTM C 39 untilfailure. The compressive strength test results of 28 days silica fume concrete is represented in table 3.

The test results reported that incorporation of silica fume in the concrete increases the compressive strength in the range of $3-11 \%$ in comparison with normal concrete.

The proposed equation for predicting compressive strength is given below

$f^{\prime}{ }_{C S}(M P a)=61.60+0.6072 S_{\mathbf{f}}$

Withreference to the above equation, the compressive strength of the concrete can be easily predicted with the corresponding percentage of silica fume. The predicted results match with the experimental results, and the prediction error is not more than $2.0 \%$.

Table 3: Comparison of measured and predicted values of compressive strength

\begin{tabular}{|c|c|c|c|c|}
\hline $\begin{array}{c}\text { Silica } \\
\text { fume \% }\end{array}$ & $\begin{array}{c}\text { Compressive } \\
\text { strength(MPa) }\end{array}$ & $\begin{array}{c}\text { Strength } \\
\text { effectiveness (\%) }\end{array}$ & $\begin{array}{c}\text { Predicted } \\
\text { value(MPa) }\end{array}$ & $\begin{array}{c}\text { Prediction } \\
\text { Error (\%) }\end{array}$ \\
\hline 0 & 61.23 & 0 & 61.60 & -0.60 \\
\hline 3 & 63.45 & 3.6 & 63.42 & 0.05 \\
\hline 6 & 65.24 & 6.5 & 65.24 & 0.00 \\
\hline 9 & 67.23 & 9.7 & 67.06 & 0.25 \\
\hline 12 & 68.34 & 11.61 & 68.89 & -0.8 \\
\hline 15 & 67.45 & 10.16 & 67.71 & -1.81 \\
\hline
\end{tabular}

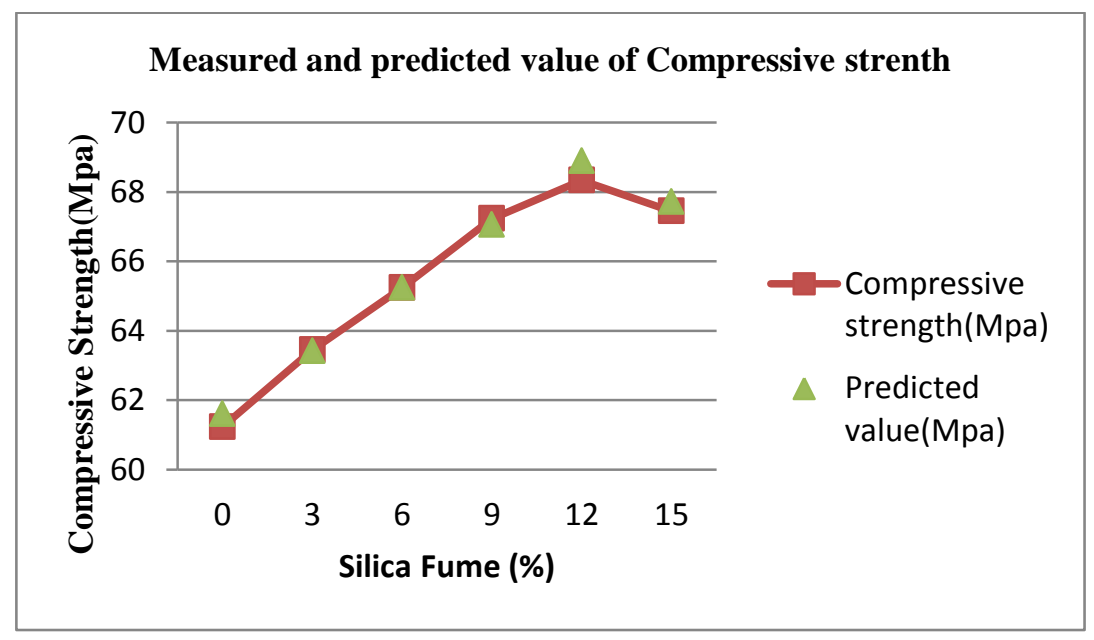

Fig. 1: Effect of silica fume percentage on compressive strength

\subsubsection{Splitting Tensile Strength Test}

The splitting tensile test on cylinder specimens was carried out in accordance with ASTM C 496, Addition of Silica fume significantly increases Split tensile strength (9-13\%). The Split tensile strength test results of 28 days silica fume concrete is represented in table 4 .

The proposed equation for predicting Split tensile strength is given below:

$\mathrm{f}_{\mathrm{ST}}(\mathrm{MPa})=\mathbf{4 . 3 7 6 + 0 . 0 3 4 S _ { \mathrm { f } }}$ 
Withreference to the above equation, the Split tensile strength of the concrete can be easily predicted with the corresponding percentage of silica fume. The predicted results match with the experimental results, and the prediction error is below $5.5 \%$.

Table 4: Comparison of measured and predicted values of compressive strength

\begin{tabular}{|c|c|c|c|c|}
\hline $\begin{array}{c}\text { Silica } \\
\text { fume (\%) }\end{array}$ & $\begin{array}{c}\text { Split tensile } \\
\text { strength(Mpa) }\end{array}$ & $\begin{array}{c}\text { Strength } \\
\text { effectiveness (\%) }\end{array}$ & $\begin{array}{c}\text { Predicted } \\
\text { value(Mpa) }\end{array}$ & $\begin{array}{c}\text { Prediction Error } \\
(\%)\end{array}$ \\
\hline 0 & 4.16 & 0 & 4.376 & -5.19 \\
\hline 3 & 4.62 & 9.96 & 4.478 & 3.07 \\
\hline 6 & 4.68 & 11.11 & 4.58 & 2.14 \\
\hline 9 & 4.76 & 12.61 & 4.682 & 1.64 \\
\hline 12 & 4.80 & 13.33 & 4.784 & 0.33 \\
\hline 15 & 4.76 & 12.61 & 4.65 & 2.3 \\
\hline
\end{tabular}

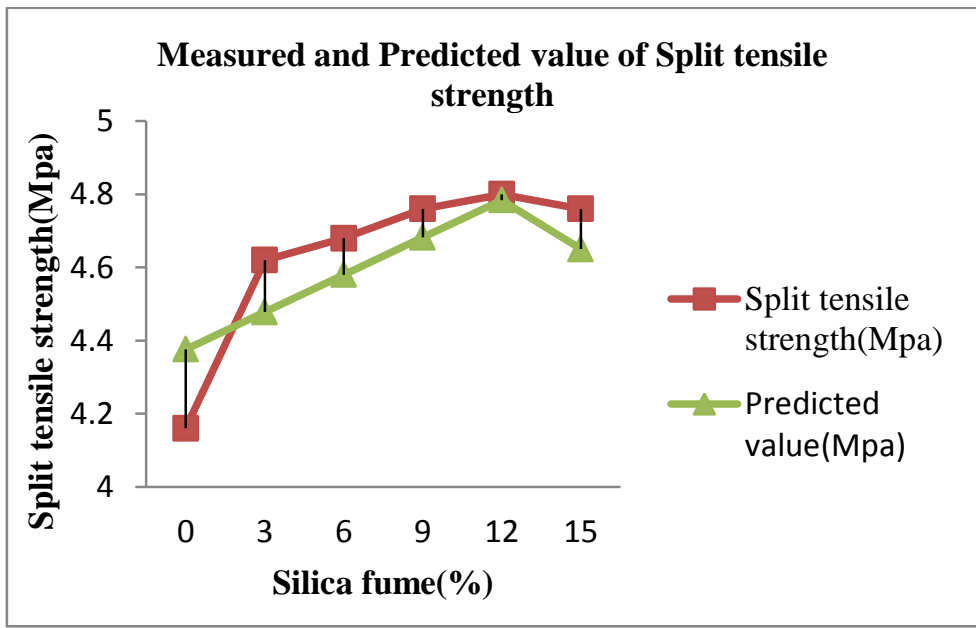

\subsubsection{Flexural Strength Test}

Fig. 2: Effect of silica fume percentage on Split tensile strength

The prisms were tested under three-point loading in accordance with ASTMC 78 and ASTMC 1108.

Flexural strength of silica fume concrete found to beincreased in the range of 5-14\% as compared to the normal Concrete without silica fume. The Flexural strength test results of 28 days silica fume concrete is represented in table 5.

The proposed equation for predicting Flexural strength is given below:

$\mathrm{f}_{\mathrm{R}}(\mathrm{Mpa})=\mathbf{4 . 3 7 6}+\mathbf{0 . 0 3 4 \mathrm { S } _ { \mathrm { f } }}$

With reference to the above equation, the Flexural strength of the concrete can be easily predicted with the corresponding percentage of silica fume. The predicted results match with the experimental results, and the prediction error is below $3 \%$.

Table 5: Comparison of measured and predicted values of Split tensile strength

\begin{tabular}{|c|c|c|c|c|}
\hline $\begin{array}{c}\text { Silica } \\
\text { fume (\%) }\end{array}$ & Flexural strength(Mpa) & $\begin{array}{c}\text { Strength } \\
\text { effectiveness (\%) }\end{array}$ & $\begin{array}{c}\text { Predicted } \\
\text { value(Mpa) }\end{array}$ & Prediction Error (\%) \\
\hline 0 & 7.00 & 0.00 & 7.07 & -0.20 \\
\hline 3 & 7.14 & 2 & 7.23 & -1.31 \\
\hline 6 & 7.39 & 5.5 & 7.39 & -0.03 \\
\hline 9 & 7.70 & 10.7 & 7.55 & 1.93 \\
\hline 12 & 7.98 & 14 & 7.89 & 1.12 \\
\hline 15 & 7.68 & 9.7 & 7.87 & -2.46 \\
\hline
\end{tabular}




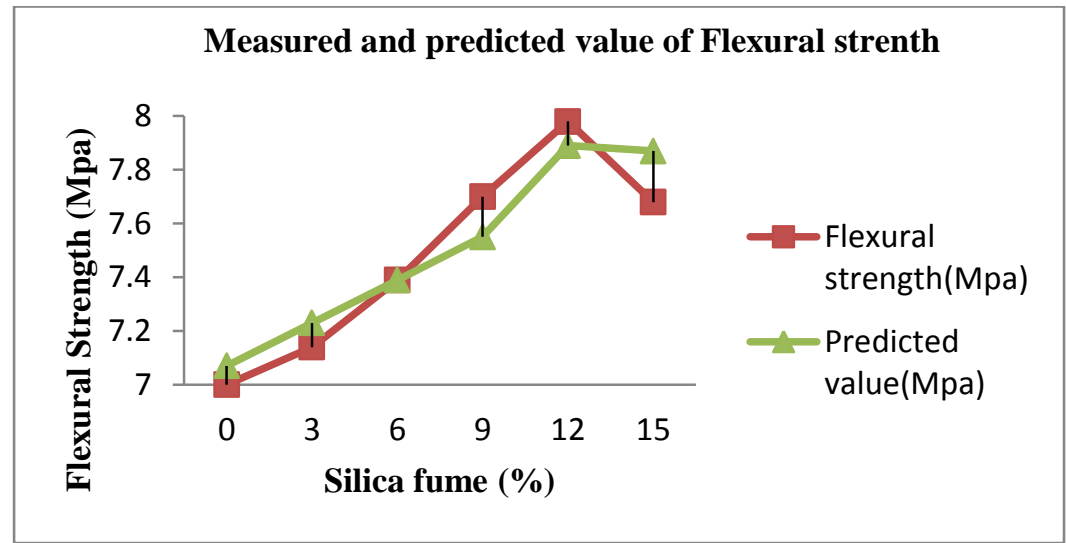

Fig. 3: Effect of silica fume percentage on Flexural strength

\section{Conclusion}

Based on the Experimental results, the following conclusions were drawn:

1. The strength of the concrete increases considerably from 9 to $12 \%$ due to silica fume addition

2. Replacement of cement up to $12 \%$ of silica fume attains better results compared to normal concrete without silica fume.

3. Based on strength effectiveness, it is observed that compressive strength, split tensile \& flexural strength of M60 concreteare increased as $11 \%, 13 \%$ and $14 \%$.

4. Silica fume seems to have more prominent effect on the flexural strength than the compressive and split tensile strength.

5. Silica fume attains better result than the plain cement concrete at 28 days.

6. This paper presents the mathematical model for predicting the strength of the silica fume high strength concrete and the results from this study recommends that the model achieve remarkably well in predicting the strength of concrete mix.

\section{References}

[1] Umesh Sharma, AnkitaKhatri, and Abhishek Kanoungo, Use of Micro silica as Additive to Concrete-state of Art, International Journal of Civil Engineering Research,5(1),2014,9-12

[2] S. Bhanja, B.Sengupta, Influence of Silica fume on the tensile Strength of concrete, Cement and Concrete Research 35, $2005,743-747$.

[3] N.K. Amudhavalli, Jeena Mathew, Effect of Silica fume on strength and Durability Parameters of Concrete,International journal of Engineering Sciences \&Emerging Technologies,3(1), 2012, 28-35.

[4] Muhannad Ismeik, Effect of Mineral Admixture on Mechanical Properties of HighStrength concrete made with locally Available Materials, Jordan Journal Of Civil Engneering,3(1), 2009, 78-90.

[5] Mohammad Panjehpour, Abang Abdullah Abang Ali, Ramazan Demirboga, Silica Fumes And its Effects on concrete Properties, International Journal of Sustainable Construction Engineering andTechnology, 2(2), 2011, 1-7.

[6] J.M.R.Dotto, A.G. De Abreu, D.C.C.Dal molin, I.L.Muller, Influence of Silica Fumes Addition on Concrete physical Properties and on Corrosion Behaviour of Reinforcement Bars, cement and Concrete composites, 26, 2004, 31-39.

[7] Verma Ajay, Chandak Rajeev, and R.K.Yadav, Effect of Micro Silica on The Strength of Concrete, Research Journal of Engineering Sciences, 1(3), 2012, 1-4.

[8] Sumit Kumar, ArvindDewangan, LakhanNagpal, SandeepDhiman, Ordinary Portland Cement, Research Journal of Engineering Sciences, 1(3),2012, 1-4.

[9] Vikas Srivastava1, V.C. Agarwal and Rakesh Kumar, Effect of Silica fume on mechanical properties of Concrete, J. Acad. Indus, 1(4), September( 2012), 176-179.

[10] PawadePrashant.Y, Nagarnaik P.B, Pande A.M , Influence of Silica fume in enhancement of compressive strength and flexural strength of steel fibers concrete and their relationship, International Journal Of Civil And Structural Engineering, 2(1), $2011, \mathbf{4 4}-\mathbf{5 5}$.

[11] Sumit Kumar, ArvindDewangan, LakhanNagpal, and SandeepDhima, Significance of Silica Fume in Enhancing the Quality of Concrete, International Journal of Innovative Technology and Exploring Engineering , 2(6) ,2013, 120-123.

[12] American concrete Institute ACI544.4R-88(2000) Guide for the Use of Silica Fume in Concrete.

[13] ASTM C -39/C39m-99 (1999) Standard test method for Compressive strength of cylindrical concrete specimens.

[14] ASTM C 78/94 (1994) Standard Test Method for Flexural Strength of Concrete (Using Simple Beam with Third-Point Loading.

[15] ASTMC 496M-04 (2004) Standard Test Method for Splitting Tensile Strength of Cylindrical Concrete Specimens.

[16] GurbirKaur, S P Singh, and S K Kaushik, Flexural Fatigue Strength of Steel Fibre Reinforced Concrete Containing Blends of Limestone Powder and Silica Fume, International Journal of Emerging Technology and Advanced Engineering, 2(6), 2012, 436-445.

[17] Ajay Verma, Dr Rajeev Chandak, R.k.Yadav, A Review For Characterization Of Silica Fume And Its Effect On Concrete With Pozzolonic Portland Cement, International Journal of Scientific \& Engineering Research, 4(1), 2013, 1-7.

[18] Des King, The Effect Ofsilica Fume On The Properties Of Concrete Asdefinedin Concrete Society Report 74, Cementitious Materials,

[19] B.L.P Swami, P.SrinivasaRao, and P.S.S Narayana, Studies on cement replacements by micro silica 920 -D: Proc. $30^{\text {th }}$ Conf. on Concrete and Structures ,Singapore ,2005.

[20] M.Mazloom, A.A.Ramezanianpour, Long term effects of silica fume on high strength concrete columns, Proc. $28^{\text {th }}$ Conf. on Concrete and Structures ,Singapore ,2003, 389-396. 